\title{
Business Analysis and Audit of Foreign Economic Activity of the Enterprise
}

\author{
KARINA NAZAROVA ${ }^{1}$, OLGA ZAREMBA ${ }^{2}$, MARIIA NEZHYVA ${ }^{3}$, \\ VOLODYMYR HORDOPOLOV ${ }^{4}$, VIKTOR HARBAR ${ }^{5}$, VASIL GOROVYJ ${ }^{6}$ \\ 1,2,3,4 Department of Financial Analysis and Audit, KYIV NATIONAL UNIVERSITY OF TRADE AND ECONOMICS, \\ UKRAINE.
}

${ }^{5}$ Vinnitsa Institute of Trade and Economics, KYIV NATIONAL UNIVERSITY OF TRADE AND ECONOMICS, UKRAINE. E-mail: artorix@ukr.net

${ }^{6}$ Department of Management named after professor I. S. Zavadsky, NATIONAL UNIVERSITY OF LIFE AND ENVIRONMENTAL SCIENCES OF UKRAINE, UKRAINE.

\begin{abstract}
Based on the substantiation of the necessity of changes in the management system of the enterprise in order to increase Ukraine's level in international economic ratings, a comprehensive model of the transformation of theoretical and methodological principles of accounting, analysis and audit in the management of foreign economic activity was developed. An approach to the formation of the accounting, analysis and audit principles of the enterprise's foreign economic activity, which takes into account the differentiation of decisions made in the system of management of foreign economic activity, it allows using the environment of the business entity to improve the efficiency of the implementation of foreign economic transactions. The basis of the theoretical and methodological principles of audit in the part of the suggested model of the transformation of the accounting system of transactions of foreign economic activity, which consists of tasks, elements of the method and objects of accounting, which form different processes of the types of foreign economic transactions, and provides increasing of the reliability of accounting information support, as it takes into account the influence of the internal and external environment of the enterprise. The methodical principles of the audit of export and import transactions of enterprises in the part of suggestions for improvement of documentary support, formation of the value of imported goods and reflection on the analytical accounting accounts of export-import transactions with goods, which increases the efficiency and reliability of the formation of responses to information requests of the system of management of foreign economic activity, was developed. The directions of improvement of the organizational and methodical provisions of audit for foreign economic activity of enterprises are grounded, taking into account changes in the tendencies of development of foreign economic activity at the micro and macro levels. The peculiarities of application of internal and external methods of management of currency risks in the system of enterprise accounting as an effective management tool were disclosed. It is reflected as the influence of the external environment in the accounting system and forms information support for users who make decisions on planning and development of foreign economic activity of the enterprise. The stages of obtaining foreign investments in accounting were substantiated, which promotes the modification of the methodological support of audit of foreign investments as the basis for the formation and improvement of the investment climate.
\end{abstract}

Keywords: foreign economic activity, currency risk hedging, accounting, analysis, audit

JEL Classification: F15; M21; M42 


\section{Introduction.}

Activities on providing Ukrainian services to foreign economic entities are one of the types of foreign economic activity. These services include: production, transport and forwarding, insurance, consulting, marketing, export, management, accounting, auditing, legal, and others [1]. One of the main directions that will expand the scope of Ukraine's foreign trade activities in the area of importexport of services is the confidence of the participating countries participating in such operations to the domestic system of customs procedures and investment climate in the country. It is therefore extremely important to pursue an effective foreign economic policy that would create the most favorable environment for participants of foreign economic activity in order to intensify the implementation of their export-import operations.

\section{The theoretical basis for the development of marketing strategy for the enterprise's financial growth.}

\subsection{Features of a strategic approach in formation of marketing activities.}

The issue of foreign economic activity of enterprises is the focus of many scholars and practitioners. L. Krymchak and E. Rudnichenko [2] investigates mechanisms for improving the information component of economic security of foreign economic activity of domestic enterprises in the context of their interaction with customs authorities. I. Fedorenko, Yu. Kolomiyetsa and K. Kolomoytseva [3], O. Prokopenko and Yu. Bojko [4] study the current state of foreign economic activity of trade enterprises of Ukraine in terms of their competitiveness in the world market of goods and services. It is determined that the basis of any competitive foreign economic activity of trade enterprises is the successful implementation of import and export operations by trade entities, which depends on the constant assessment of their own capabilities and regular development of measures to increase competitiveness. S. Kubiv and V. Fedyuk [5], L. Mura and V. Gašparíková [6], V. Boiko et al. [7] study the enterprises of the agricultural sector, which are forced to constantly maintain the positive dynamics of their foreign economic activity. This becomes the basis for continuous monitoring of market innovations [8] and the search for opportunities to obtain greater economic effects by improving product quality and minimizing the cost of energy used in production, storage and transportation. L. Ivanchenkova et al. [9] investigate the theoretical and regulatory framework for accounting and analysis of enterprise innovation costs. Mathematical tools are used to assess the level of economic efficiency of the foreign economic activity process, which, unlike the existing ones, takes into account the possibility of analyzing the relationship between the dynamics of growth of the key indicator of foreign economic activity relative to the relative duration and cost of this process. activities in three-dimensional space relative to two common parameters simultaneously. M. Pedan [10] study role of strategic marketing in improving the efficiency of foreign economic activity of domestic enterprises. N. Galaziuk and O. Sereda [11] study theoretical aspects of foreign economic activity of modern enterprises. O. Bilousov, G. Zhuikov and S. Bilousova [12] examines the essence of public administration of foreign economic activity of Ukraine in the context of state mechanisms of regulation of its economy. O. Zelinska [13] study conceptual approaches to improvement foreign economic activity of the region in conditions euroregional cooperation.

T. Berezyanko and E. Novikova [14] study the current state of development of the ventilation equipment market in Ukraine. Established a positive trend in exports of ventilation equipment to countries with dry climates. Identified a potential market for export expansion. O. Akymenko [15] explores foreign economic relations, which are a determining factor in the development and modernization of the economy, an important step towards solving many social problems and a driver of scientific and technological development. The revival of foreign economic activity will promote the country's integration into the international economic space and will determine it not just as a partnership and mutually beneficial cooperation, but as a process that will serve as an effective means of solving global problems of mankind. T. Rybakova [16] investigates the essence and approaches to the definition of currency regulation of foreign economic activity allows considering it 
as an instrument of currency policy and an integral part of foreign economic policy, state regulation of the economy, financial regulation of foreign economic activity. Indirect and direct currency regulations define its regulatory and control functions. Thereafter the exchange rate and currency transactions should be considered as the main instruments of currency regulation of foreign economic activity. V. Fesenko and L. Babenko [17] investigates the areas of foreign economic activity of enterprises, which are characterized by a high risk of fraud, which requires special attention when conducting inspections. Analyzes the main problematic issues of accounting and taxation in foreign trade transactions and their impact on the formation of audit procedures. Identifies the priority areas of audit of foreign economic transactions as a component of independent audit of financial statements and tax control.

The mentioned scientists studied current trends and factors of development of foreign trade of Ukraine as a whole and in the part of analysis, accounting and audit in particular. However, taking into account time requirements, there is a need to transform the system of principles and objectives of audit, accounting and analysis in line with their development in the context of currency risks, foreign investment and trade operations in the conditions of sustainable development of the state.

The aim of the article is grounding of practicability, generalization and developing of scientific and theoretical provisions and recommendations to improve the process of analysis and audit of the foreign economic activity of the enterprise in ensuring sustainable development of the state.

\subsection{Algorithm for developing an enterprise marketing strategy.}

Scientists have studied trends and factors in the development of foreign trade in general and in particular in terms of analysis, accounting and auditing. However, taking into account the requirements of time, we have studied the system of principles and objectives of auditing, accounting and analysis in accordance with their development in the context of currency risks, foreign investment and trade operations in the context of sustainable development.

\section{Methodology.}

The basis of the theoretical and methodological principles of audit in the part of the suggested model of the transformation of the accounting system of transactions of foreign economic activity, which consists of tasks, elements of the method and objects of accounting, which form different processes of the types of foreign economic transactions, and provides increasing of the reliability of accounting information support, as it takes into account the influence of the internal and external environment of the enterprise. The methodical principles of the audit of export and import transactions of enterprises in the part of suggestions for improvement of documentary support, formation of the value of imported goods and reflection on the analytical accounting accounts of export-import transactions with goods, which increases the efficiency and reliability of the formation of responses to information requests of the system of management of foreign economic activity, was developed. The directions of improvement of the organizational and methodical provisions of audit for foreign economic activity of enterprises are grounded, taking into account changes in the tendencies of development of foreign economic activity at the micro and macro levels. The peculiarities of application of internal and external methods of management of currency risks in the system of enterprise accounting as an effective management tool were disclosed. It is reflected as the influence of the external environment in the accounting system and forms information support for users who make decisions on planning and development of foreign economic activity of the enterprise. The stages of obtaining foreign investments in accounting were substantiated, which promotes the modification of the methodological support of audit of foreign investments as the basis for the formation and improvement of the investment climate.

The hypothesis of the research is that the improvement of theoretical, methodological and practical principles of accounting, analysis and audit of foreign economic operations of the enterprise 
will increase the efficiency of foreign economic activity of the business entity and will have a positive impact on investment attractiveness.

\section{Results.}

The state strategy of regional development for the period up to 2020 defines the objectives of regional policy in the field of support of attraction of investments, including foreign direct investment. One of them is the simplification of customs procedures by introducing a customs control system based on the results of risk analysis and customs post-audit and reducing the number of documents submitted for customs clearance [18].

Foreign economic activity is a multidimensional integrated system of management. It attracts two main subsystems: foreign trade and international production and investment activities [19]. In recent years, the issue of foreign economic activity of enterprises has been substantially updated, as evidenced by statistical data: in terms of trade - the export of goods in Ukraine in 2019 amounted to 47339935.2 thousand dollars. The USA, which is $9.4 \%$ more than in 2018 , and imports -57141041.5 thousand dollars. The USA, which is by $15.2 \%$ more than in the previous year; in the part of investments - share capital of non-residents in the economy of Ukraine as of 01.01.2020 is 40020.9 million dollars. The USA, in turn, equity capital in the economies of the countries of the world residents of Ukraine is 6322.0 million dollars [20]. This situation shows the need to develop a toolkit for the system of management of foreign economic activity of enterprises in terms of financial audit and analysis in the conditions of sustainable development of the state.

Information display, audit and analysis of operations of foreign economic activity of the enterprise depend on the type and scope of activity, on the type and size of the external market in which the entity carries out activities, on the principles of functioning of the management system in the middle of the enterprise, etc. It should be noted that the process of audit and analysis is not possible without an adequate information base, which is formed in the accounting subsystem of the entity, which also provides for the creation of information support for the foreign economic activity of the enterprise.

Undertakings of the economy of Ukraine, guided by the current legislation, can use in accounting and financial reporting not only the principles defined in the Ukrainian legislation, but also apply other principles presented by international accounting and auditing standards. Compliance with the accounting principles of analysis and audit reduces the possibility of distortion and falsification of financial statements. Approaches to the formation of the principles of accounting, analysis and audit of the foreign economic activity of the enterprise should take into account the differentiation of decisions taken in the system of management of foreign economic activity, and especially the functioning of the communication space between them.

The quality and reasonableness of management decisions based on information accounting depends, first of all, on the establishment of communication links between the structural divisions of the enterprise. Therefore, we have identified the features of creating a communication space between the structural divisions of the enterprise, which carries out foreign economic activity. In fig. 1 presents the process of creating the communication space of the system of management of foreign economic activity, taking into account requirements to the subsystems of the audit of analysis and accounting as an information base. The communication space is decisive in the formation of relations between the structural divisions of enterprises. The presented process of creating a communication space between the system of management of foreign economic activity and its subsystems of analysis, audit and accounting ensures the formation of a well-established management of foreign economic activities, as well as the basis for reforming the accounting system of the enterprise, which should take into account the influence of managerial decisions in the field of foreign economic activity. 
Figure 1. Creating a communication space for the management system foreign economic activity (source: compiled by the authors)

Communication space of foreign economic activity of the enterprise

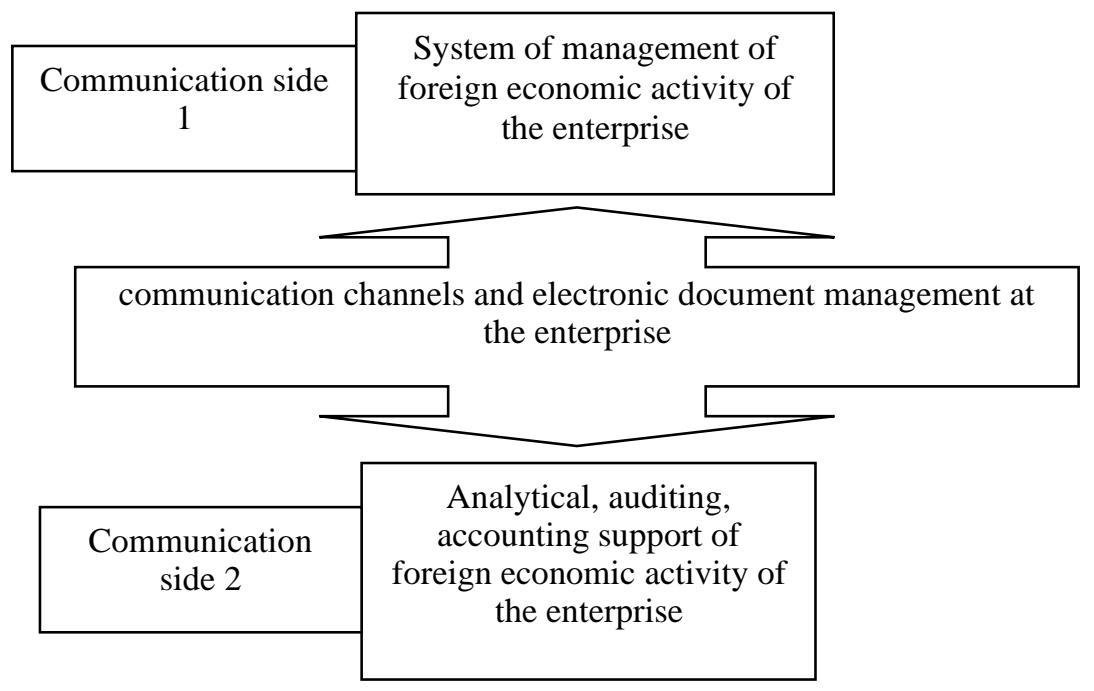

The results of foreign economic activity are evaluated not only within each enterprise in the form of various reports, but also affect the sustainable development of the state. According to the World Economic Forum, Ukraine ranks 81st out of 137 countries according to the Global Competitiveness Index (GCl) from 2018-2019. Compared to $\mathrm{GCl}$ 2017-2018, the country has risen to 4 positions, however, according to the GCl 2016-2017, it lost two positions (ranked 79th) [21]. For the Global Competitiveness Index it is expedient to evaluate not only quantitative values, but also to assess the internal indicators that form the general place of the country in the international rating. The World Economic Forum highlights the following disadvantages for foreign trade activities, including border corruption, burdensome import procedures, high costs or delays caused by inland traffic, inappropriate telecommunication infrastructure, high costs or delays caused by international traffic, crime and theft, internal technical requirements and standards, burdensome procedures on the border with foreign countries, high costs or delays caused by international border traffic, tariff barriers abroad, requirements for rules of origin, corruption at the border [22]. Internal factors should also include an effective mechanism of audit and analytical support for the processes of export-import operations of the enterprise. We propose a model for the transformation of the accounting system for foreign trade operations, which is an information base for conducting audit and analytical procedures of foreign economic activity, which consists of tasks, elements of the method and objects of accounting, which form different processes of types of foreign economic operations, and also ensures an increase in reliability accounting and information support, since it takes into account the impact of the internal and external environment of the enterprise. The tasks include ensuring the formation of reliable and comparable financial and non-financial statements, on the basis of which planning is carried out for subsequent reporting periods; preparation and interpretation of accounting information for satisfaction of interests and requests of groups of internal and external users. The elements of the method and objects of accounting include documentation, inventory, control (audit) and the entire system of management of foreign economic activity of the enterprise.

An integral part of the process in the foreign economic activity of the enterprise is the documentation of tax operations, customs clearance, settlement and other issues that require a unified approach to create the possibility of implementing effective operations of foreign economic activity for their analysis and audit. Documentation of export-import operations is interpreted at all stages of the implementation of foreign economic operations and should ensure the reliability of 
data that is reflected in the account on the basis of the transformation of information contained in primary documents. N. Karpenko [23] indicates the list of necessary documents for registration of export operations crossing the customs border of the country. For the customs clearance of goods for export, representatives of the enterprise must provide the following documents:

- customs declaration (fills in the customs broker);

- the card of the person who carries out operations with the goods (accreditation card);

- $\quad$ an agreement with the customs broker;

- the foreign economic agreement (contract) with the appendices thereto, as well as their translation into the state language;

- transport documents and transportation notes (CMR, TTN, Air Way Bill, Bill of Lading), loading information, packing sheets, specifications, etc. (made by the customs broker);

- commercial documents (invoice);

- certificate of quality for the goods (if available);

- certificate of origin of goods for CIS countries (as a rule, forms ST-1), for the European Union (certificate of origin form EUR.1);

- documents which, in accordance with the legislation of Ukraine, are issued by the state authorities for the completion of customs clearance of goods (permits and marks of bodies of sanitary-epidemiological, veterinary, phytosanitary, radiological, ecological control, etc.);

- a certificate of approval of a vehicle for movement under customs seals and seals, a TIR Carnet (in case of its use);

- $\quad$ other documents at the request of the customs authorities.

As we see the list of documents is quite voluminous and requires improvement of the methodological principles of audit of export-import operations of enterprises in terms of improving their documentary support and reflection on the analytical accounting of export-import transactions with goods, which will increase the efficiency and reliability of the formation of responses to information requests of the system management of foreign economic activity.

In the practice of international business entities, there is such a concept as currency risk management since external economic activity is not possible without the use of currency. Actual questions for enterprises are accounting and control (audit) of exchange rates and recognition of income and expenses during the purchase and sale of foreign currency. The methods of currency risk management include: hedging, diversification, insurance, risk aversion method, loss reduction or loss prevention method, risk taking method, loss reduction method, risk-sharing method, risk outsourcing method, loss prevention method, and other. For example, in China companies first use natural ways to limit currency risk by regulating income and expenditure (using foreign currency loans), but only later they apply additional risk management tools [24]. Each method influences changes in the accounting and analytical system, which leads to a change in the essence of information flows in the enterprise and influences management decisions in the field of foreign economic activity. However, enterprises should use not one, but a set of methods for managing currency risks, which will optimize the cost of risk management and create the necessary conditions and opportunities for planning foreign economic activity of the enterprise. It should be noted that in science and practice distinguish between two groups of regulation of currency risks: internal and external, which are called traditional. The application of internal risk management techniques (risk acceptance, risk transfer through currency contractual clauses, diversification of risk in the form of using different foreign currencies, natural hedging) does not have a significant effect on the accounting system (except for the process of documenting and analytical accounts system), that is, it does not modify objects of accounting display. Instead, external methods (risk transfer through non-derivative instruments (foreign currency loans, foreign currency deposits, risk transfer through derivatives - hedging (futures, forwarders, options, swaps) have a reasonably modifying effect on the formation of new facilities accounting and creating information flows related to the use of derivative and non- 
derivative instruments [25-26]. As a result, we are proposing to improve the organizational and methodological approach to accounting, analysis and audit imaging of currency risk management operations that should be disclosed in the model of accounting for foreign currency financial instruments, namely, in the part of proposals for improving the order of assessment and reflection in accounting, which will ensure the formation of information support of stakeholders and promote the application of external methods of managing currency risk in the audit [27-28].

In assessing the current state of analytical support for foreign trade operations, it is necessary to analyze the factors that determine the objects of the audit and influence their changes in the foreign economic activity of enterprises [29-31]. Such factors are classified exogenously (external) and endogenous (internal). External (exogenous) factors include the following:

- economic - the type of economic system of the country, the level of economic development and the country's place in the world economic system determine the possibility of foreign economic activity by enterprises and the advantages of entering the external markets of goods and services, capital, etc., associated with the participation of the country in international organizations (for example, World Trade Organization, International Monetary Fund, European Union, etc.);

- legal - normative regulation of foreign economic activity and fiscal, currency, customs and foreign policy in the country affect the accounting reflection of operations through economic, customs, currency and tax regulations of the legislation;

- internal (endogenous) factors are formed under the influence of development of the enterprise, entering the external market: type and scope of the enterprise; price competitiveness of the subject of foreign economic contract (goods, services, etc.);

- forms of settlements for foreign economic operations of the enterprise; system of production and sale of finished goods, as well as sales of goods, services and works; organizational learning and knowledge capital [32-34].

In our opinion, the organization and conduct of economic activity in foreign markets of goods and services, capital is also exposed to endogenous factors that are related to the peculiarities of the entity's activity and are identified as internal factors. Factors of external influence are uncontrollable, unpredictable and often not evaluable. It is necessary to improve the organizational and methodological provisions of the audit of foreign economic activity of enterprises taking into account changes in trends in the development of foreign economic activity at the micro and macro levels and taking into account exogenous (which do not) depend on the activity of the enterprise) and endogenous (depending on the enterprise) factors of influence of the system of external economic relations in Ukraine on the formation of organizational and methodological support for accounting, analysis and audit of foreign economic activity of enterprises [35-36].

The European Business Association calculates an investment attractiveness index every year, which estimates the country and its ability to attract foreign investment. Thus, in particular, in 2018, the indicator was 3.03 points on a 5-point scale (Lykert scale). In the first half of 2018, the index left the negative plane for the first time since 2011. In the first half of 2018 the index was equal to 3.15 points. Last year it was 2.88 and 2.85 points in June and December respectively [25]. This situation shows a low interest of foreign investors in the Ukrainian economy. One of the reasons for this situation is an imperfect information base for the formation of positive investor conclusions about the appropriateness of investments. The accounting system is the main information source at the enterprise, in which the processes of storage, processing, transfer and interpretation of data on the economic activity of enterprises for the implementation of analysis and audit are taking place. Therefore, it is necessary to substantiate the stages of attracting foreign investments, which will help to change the methodological provision of audit of foreign investments as the basis for the formation and improvement of the investment climate for both micro-level entities and the country as a whole. International and national accounting and financial reporting standards determine similar methods for assessing the inflow of financial investments depending on their types, but the approach to investment classification is different (international standards are more detailed and related to the 
choice of the method of valuation of objects of accounting) [26]. A feature of international accounting standards is that, unlike national ones, they regulate the issue of determining the financial result of the sale of financial investments [37]. Taking into account domestic and international practice, we have formed the stages of attracting foreign investment:

- conducting negotiations with potential investors and obtaining a positive response on receiving foreign investments;

- initial assessment of foreign investment in foreign and national currency;

- display of transactions with foreign investments in accounts;

- revaluation of the value of foreign investments and reflection of the results of investment activity;

- termination of operations with foreign investments received.

The given stages from the receipt to the elimination of foreign investments are singled out in the light of reflection in the account accounts in order to formulate analytical information for making managerial decisions in the field of creating an investment attractiveness of the entity.

\section{Conclusions.}

Thus, in the article a theoretical generalization was carried out and a complex solution of the scientific and practical problem concerning the development of the analytical and audit system of management of the foreign economic activity of the enterprise in the plans of sustainable development of the economy was proposed.

\section{References}

1. On Foreign Economic Activity: Law of Ukraine, April 16, 1991 № 959-XII. Retrieved form https://zakon.rada.gov.ua/laws/show/959-12\#Text.

2. Krymchak, L., \& Rudnichenko, E. (2019). Improving the information component of economic security of foreign economic activity of domestic enterprises in the context of the implementation of the main provisions of post-customs audit. Business Inform, 7, 211-216.

3. Fedorenko, I., Kolomiyets, Yu., \& Kolomoytseva, K. (2020). Analysis of foreign economic activity as a component of the mechanism of management of competitiveness of trade enterprises. Black Sea Economic Studies, 58, 56-62.

4. Prokopenko, O.V., \& Bojko, Yu.V. (2010). The improvement of the scientific-methodological approach to assessment of product competitiveness on the international market. Marketing and Management of Innovations, 2, pp. 22-25.

5. Kubiv, S., \& Fedyuk, V. (2020). Method of selection of indicators that characterize the development of foreign economic activity during the solution of specific management problems. State and Regions. Series: Economics and Entrepreneurship, 5, 55-59.

6. Mura, L., Gašparíková, V. (2010). Penetration of small and medium sized food companies on foreign markets. Acta Universitatis Agriculturae et Silviculturae Mendelianae Brunensis, 58(3), pp. 157-163.

7. Boiko, V., Kwilinski, A., Misiuk, M., \& Boiko, L. (2019). Competitive Advantages of Wholesale Markets of Agricultural Products as a Type of Entrepreneurial Activity: The Experience of Ukraine and Poland. Economic Annals-XXI, 175(1-2), 68-72. https://doi.org/10.21003/ea.V175-12

8. Filipova M., Yuleva-Chuchulayna R. (2020). Innovation projects as a factor for strategic development of small and medium - sized enterprises. Revista Inclusiones, 7(3), pp. 461-476.

9. Ivanchenkova, L., Skliar, L., Pavelko, O., Cheban, Y., Kuzmenko, H., Zinkevych, A. (2019). Improving accounting and analysis of innovative costs. International Journal of Innovative Technology and Exploring Engineering, 9(1), pp. 4003-4009. 
10.Pedan, M. (2019). Peculiarities of building a system of strategic marketing of foreign economic activity of enterprises. Scientific herald of the Uzhhorod National University. Series: International Economic Relations and the World Economy, 28, 61-64.

11.Galaziuk, N., \& Sereda, O. (2018). Necessity of improvement of management of foreign economic activity of the enterprise in modern conditions. Economic sciences. Series: Economic theory and economic history, 15, 54-62.

12.Bilousov, O., Zhuikov, G., \& Bilousova, S. (2020). The essence of state management of foreign economic activity (FEA) of Ukraine. Business Navigator, 4, 38-45.

13.Zelinska, O. (2020). Conceptual approaches to improving the foreign economic activity of the region in terms of Euroregional cooperation. Innovatsiina ekonomika, 5, 5-12.

14.Berezyanko, T., \& Novikova, E. (2019). Strategic management of the enterprise in the field of foreign economic activity. Effective economy, 1. Retrieved form

http://nbuv.gov.ua/UJRN/efek_2019_1_3.

15.Akymenko, O. (2020). Assessment of the competitiveness of industrial production influence on foreign economic activity development under the conditions of globalization. Problems and prospects of economics and management, 2, 51-59.

16.Rybakova, T. (2020). The instruments of currency regulation of foreign economic activity. Economic Bulletin of the University, 47, 127-135.

17.Fesenko, V., \& Babenko, L. (2016). Audit of foreign economic activity of enterprises as a factor of economic security: priorities and problems. Effective economy, 10. Retrieved form http://nbuv.gov.ua/UJRN/efek_2016_10_20.

18.The state strategy of regional development for the period till 2020, from August 6, 2014 № 385. Retrieved form http://zakon3.rada.gov.ua/laws/show/385-2014-ח.

19.Kozak, Yu., Prytula, N., Ermakova, A. (2016). Foreign-economic activity: enterprise-region. Center for Educational Literature.

20.Foreign trade of certain types of goods by countries of the world, State Statistics Committee of Ukraine, 2020. Retrieved form http://www.ukrstat.gov.ua/.

21.Schwab, K. (2016). The Global Competitiveness Report 2016-2017, World Economic Forum, Geneva. Retrieved form http://www3.weforum.org/docs/GCR20162017/05FullReport/TheGlobalCompetitivenessReport2016-2017_FINAL.pdf.

22.Schwab, K. (2016). The Global Enabling Trade Report 2016, World Economic Forum, Geneva. Retrieved form http://www3.weforum.org/docs/WEF_GETR_2016_report.pdf.

23.Karpenko, N. (2017). Features of accounting of export of goods. Accounting, analysis and audit. Mukachevo State University, 1, 1134-1138.

24.Ksendzuk, V. (2015). Accounting and analysis of hedging currency risks: the dissertation author's abstract for the degree of candidate of economic sciences: specialty 08.06.04, Zhytomyr, 21.

25.Fiala, T. (2017). Press release Summarize the results of the year: How investors evaluated the business climate in Ukraine in the 2nd half of 2018, European Business Association. Retrieved form https://eba.com.ua/wp-content/uploads/2017/12/Release_IAI_2_half_2017_UKR.pdf.

26.Shepelyuk, V. (2017). National and international standards for accounting for financial investments: differences, shortcomings, ways of harmonization. Eastern Europe: Economics, Business and Management, 2. Retrieved form http://easterneurope-ebm.in.ua/journal/7_2017/59.pdf.

27.Nazarova, K., Mysiuk, V., Gordopolov, V., Koval, V., \& Danilevičienė, I. (2020). Preventional audit: implementation of SOX control to prevent fraud. Business: Theory and Practice, 21(1), 293-301. https://doi.org/10.3846/btp.2020.11647

28. Hutsaliuk, O., Koval, V., Tsimoshynska, O., Koval, M., Skyba, H. (2020). Risk Management of Forming Enterprises Integration Corporate Strategy. TEM Journal, 9(4), 1514-1523. https://doi.org/10.18421/TEM94-26 
29.Dankeieva, O., Solomianiuk, N., Strashynska, L., Fiedotova, N., Soloviova, Y., \& Koval, V. (2021). Application of Cognitive Modelling for Operation Improvement of Retail Chain Management System. TEM Journal, 10(1), 358-367. https://doi.org/10.18421/TEM101-45

30.Arsawan, I. W. E., Koval, V., Duginets, G., Kalinin, O., \& Korostova, I. (2021). The impact of green innovation on environmental performance of SMEs in an emerging economy. E3S Web of Conferences, 255, 01012.

31.Yeshchenko, M., Koval, V., \& Tsvirko, O. (2019). Economic policy priorities of the income regulation. Espacios, 40 (38), 11.

32.Arsawan, I., Wirga, I. W., Rajiani, I., \& Suryantini, N. P. S. (2020). Harnessing knowledge sharing practice to enhance innovative work behavior: the paradox of social exchange theory. Polish Journal of Management Studies, 21.

33.Arsawan, I. W. E., Koval, V., Rajiani, I., Rustiarini, N. W., Supartha, W. G., \& Suryantini, N. P. S. (2020). Leveraging knowledge sharing and innovation culture into SMEs sustainable competitive advantage. International Journal of Productivity and Performance Management.

34.Arsawan, I. W. E., Sanjaya, I. B., Putra, I. K. M., \& Sukarta, I. W. (2018). The effect of expatriate knowledge transfer on subsidiaries' performance: a moderating role of absorptive capacity. In Journal of Physics: Conference Series (Vol. 953, No. 1, p. 012082). IOP Publishing.

35.Kwilinski, A., \& Kuzior, A. (2020). Cognitive Technologies in the Management and Formation of Directions of the Priority Development of Industrial Enterprises. Management Systems in Production Engineering, 28(2), 133-138.

36.Miśkiewicz, R., \& Wolniak, R. (2020). Practical Application of the Industry 4.0 Concept in a Steel Company. Sustainability, 12(14), 5776.

37.Dzwigol, H., \& Dzwigol-Barosz, M. (2020). Sustainable Development of the Company on the Basis of Expert Assessment of the Investment Strategy. Academy of Strategic Management Journal, 19(5), 1-7. 